\title{
Usefulness of the Real-Time Reverse Transcription-Polymerase Chain Reaction Assay Targeted to $\alpha 1,4-N$-Acetylglucosaminyltransferase for the Detection of Gastric Cancer
}

\author{
Fumiaki Shimizu, Jun Nakayama, Satoshi Ishizone, Mu Xia Zhang, \\ Masatomo Kawakubo, Hiroyoshi Ota, Atsushi Sugiyama, Seiji Kawasaki, \\ Minoru Fukuda, and Tsutomu Katsuyama
}

Departments of Laboratory Medicine (FS, JN, SI, MXZ, MK, HO, TK) and Surgery (FS, SI, AS, SK), Shinshu University School of Medicine, Matsumoto, Japan; Institute of Organ Transplants, Reconstructive Medicine, and Tissue Engineering (JN), Shinshu University Graduate School of Medicine and Department of Medical Technology (HO), School of Allied Medical Sciences, Shinshu University, Matsumoto, Japan; and Glycobiology Program (MF), the Burnham Institute, La Jolla, California

SUMMARY: $\alpha 1,4-N$-acetylglucosaminyltransferase $(\alpha 4 G n T)$ is a glycosyltransferase that forms a unique glycan, GlcNAc $\alpha 1 \rightarrow 4 \mathrm{Gal} \beta \rightarrow \mathrm{R}$, specifically present in gastric gland mucous cell-type mucin. Recently, we molecularly cloned human $\alpha 4 \mathrm{GnT}$ and showed that $\alpha 4 \mathrm{GnT}$ is expressed in the mucous cells that secrete this particular mucin. In the present study, we first demonstrated that $\alpha 4 \mathrm{GnT}$ was frequently expressed in gastric cancer cells but not in peripheral blood cells using immunohistochemistry. To detect gastric cancer cells circulating in the peripheral blood of gastric cancer patients, we quantitatively analyzed the expression level of $\alpha 4 G$ nT mRNA in the mononuclear cell fraction of peripheral blood using real-time reverse transcription polymerase chain reaction. The transcripts of $\alpha 4 \mathrm{GnT}$ were detected in the mononuclear cell fraction isolated from $62.2 \%$ of 37 gastric cancer patients but not from any of 23 healthy individuals. Significant correlation was found in the expression levels of $\alpha 4 \mathrm{GnT}$ mRNA in peripheral blood and $\alpha 4 \mathrm{GnT}$ protein in gastric cancer cells. Surprisingly, $\alpha 4 \mathrm{GnT}$ mRNA was detectable in $80 \%$ of five patients with an early stage of gastric cancer when the cancer cells were limited to the gastric mucosa, and the expression levels of $\alpha 4 \mathrm{GnT}$ mRNA were increased in association with tumor progression. In three patients with gastric cancer, during postsurgical follow-up, the expression levels of $\alpha 4 \mathrm{GnT}$ mRNA were decreased after surgical removal of gastric cancer. However, significant amounts of the $\alpha 4 \mathrm{GnT}$ transcripts were again detected in two patients, who eventually developed to the recurrence of gastric cancer. Although $\alpha 4 \mathrm{GnT}$ was detected in $33.3 \%$ of nine patients with Helicobacter pylori-infected chronic active gastritis as well as all of four patients with peptic ulcer, the mean expression level of $\alpha 4 G$ nT mRNA in these benign disorders was lower than that in gastric cancer. These results altogether indicate that the quantitative analysis of $\alpha 4 \mathrm{GnT}$ mRNA expressed in the peripheral blood is useful for the detection and, possibly, monitoring of gastric cancer. (Lab Invest 2003, 83:187197).

$G$ astric cancer is the most frequently diagnosed malignancy as well as one of the leading causes of tumor death in both men and women in Japan (Sun et al, 2001). When the gastric cancer is detected in early stages, favorable outcome is expected when the tumor is completely removed by surgical procedure

DOI: 10.1097/01.LAB.0000057001.21187.A0

Received December 18, 2002.

This work was supported by Grant-in-Aids for Scientific Research on Priority Area 10178104, 14030032, and, in part, 14082201 from the Ministry of Education, Culture, Sports, Science and Technology of Japan (to JN) and by NIH Grant CA48737 from the National Cancer Institute (to $M F$ ).

Address reprint requests to: Dr. Jun Nakayama, Department of Pathology, Shinshu University School of Medicine, Asahi 3-1-1, Matsumoto 3908621, Japan.E-mail: jun@hsp.md.shinshu-u.ac.jp
(Patino, 1994). However, it also has been documented that the advanced gastric cancer showing serosal invasion frequently recurred even when the extensive resection of the primary tumor together with lymphadenectomy was performed (Boku et al, 1990; Wanebo et al, 1993). This indicates that the early detection of the gastric cancer is critical to expect favorable outcome of this disease. For the gastric mass screening, the indirect photofluorography or tumor markers such as carcinoembryonic antigen (CEA) and CA19-9 are widely used. However, it has been documented that these methods have limitation in detecting early stages of the gastric cancer when the cancer cells are restricted to the gastric mucosa (Pectasides et al, 1997).

Recently, extensive studies have been carried out to detect circulating gastric cancer cells in the peripheral blood by using the reverse transcription polymerase 
chain reaction (RT-PCR) method targeted to the specific genes including CEA and cytokeratin 19 (CK19) (Aihara et al, 1997; Majima et al, 2000; Nishida et al, 2000; Piva et al, 2000; Yeh et al, 1998). Although CEA transcripts were detected in the mononuclear cell fraction isolated from approximately 30 to $40 \%$ of patients with gastric cancer (Nishida et al, 2000; Piva et al, 2000), Piva et al (2000) reported that CEA mRNA was positive in 1 of 16 control subjects. However, CK19 mRNA was less frequently detected in the peripheral blood compared with CEA, and thus only 9.6 to $20.6 \%$ of the patients with gastric cancer were positive for CK19 transcripts (Majima et al, 2000; Yeh et al, 1998). More important, both CEA and CK19 are widely expressed not only in gastric cancer cells but also in other epithelial cell-derived tumor cells such as colorectal and breast cancers. In fact, CEA mRNA was detected in $34 \%$ of patients with colorectal cancer (Piva et al, 2000). In addition, transcripts of CK19 and CEA are inducible in hematopoietic cells in the presence of inflammatory cytokines such as interleukin-3 and interferon- $\gamma$ (Jung et al, 1998). Thus, identification of new molecules much more selectively expressed in gastric cancer cells may be helpful to improve the diagnosis of gastric cancer.

Glycoproteins secreted from the mucous cells such as mucous neck cell and pyloric gland cell of gastric mucosa and Brunner's gland of duodenal mucosa characteristically contain GlcNAc $\alpha 1 \rightarrow 4 \mathrm{Gal} \beta \rightarrow \mathrm{R}$ structures in terminal ends of the oligosaccharides in O-glycans (Ishihara et al, 1996). This unique carbohydrate is frequently expressed in the gastric cancer cells, thus being regarded as a tumor-associated carbohydrate antigen for this particular cancer (Nakamura et al, 1998). By expression cloning, we have recently isolated a cDNA encoding human $\alpha 1,4-N$ acetylglucosaminyltransferase $(\alpha 4 \mathrm{GnT})$, which is responsible for the biosynthesis of GlcNAc $\alpha 1 \rightarrow 4 \mathrm{Gal} \beta \rightarrow \mathrm{R}$ residue (Nakayama et al, 1999). In addition, Northern blot or immunohistochemical analysis using anti$\alpha 4 \mathrm{GnT}$ antibody demonstrated that this enzyme is found to be exclusively limited to the gastroduodenal mucosa as well as pancreaticobiliary tract showing gastric metaplasia, where GlcNAc $\alpha 1 \rightarrow 4 \mathrm{Gal} \beta \rightarrow \mathrm{R}$ residues are expressed (Nakayama et al, 1999; Zhang et al, 2001). These results as a whole indicate that $\alpha 4 \mathrm{GnT}$ plays a key role in forming $\operatorname{GlcNAc} \alpha 1 \rightarrow 4 \mathrm{Gal} \beta \rightarrow \mathrm{R}$ residues in vivo and may be expressed in gastric cancer cells that produce this unique glycan.

In the present study, we first demonstrated that $\alpha 4 \mathrm{GnT}$ is frequently expressed in gastric cancer cells but not in the peripheral blood cells by immunohistochemistry using a specific antibody against $\alpha 4 \mathrm{GnT}$. Then, we quantitatively measured the expression level of $\alpha 4 \mathrm{GnT}$ mRNA in the mononuclear cell fraction of peripheral blood isolated from gastric cancer patients by using real-time RT-PCR, demonstrating the clinical usefulness of this assay for the detection and monitoring of gastric cancer.

\section{Results}

\section{Expression of $\alpha 4 \mathrm{GnT}$ in Gastric Cancer Cells}

To determine whether $\alpha 4 \mathrm{GnT}$ was expressed in the gastric cancer cells, we performed immunohistochemistry of the gastric cancer tissues resected from the patients, whose blood samples had been collected before the surgery, using the anti- $\alpha 4 \mathrm{GnT}$ antibody I17K (Zhang et al, 2001). Among the 29 patients examined, $\alpha 4 \mathrm{GnT}$ seemed to be expressed in the Golgi region of gastric cancer cells in 22 patients (75.9\%), irrespective of the histopathological classifications of the gastric cancer (Fig. 1, A to C). The same experiments also demonstrated that $\alpha 4 \mathrm{GnT}$ was detected in the mucous neck cells and pyloric glands found in the normal gastric mucosa, as described before (Zhang et al, 2001) (Fig. 1D), and that the peripheral blood cells including leukocytes and lymphocytes were negative for $\alpha 4 \mathrm{GnT}$ (Fig. 1, arrows and arrowheads). These results combined suggested that the RT-PCR method targeted to $\alpha 4 \mathrm{GnT}$ mRNA would be useful to detect the circulating tumor cells in the peripheral blood of patients with gastric cancer, because $\alpha 4 \mathrm{GnT}$ was not expressed in leukocytes and lymphocytes.

\section{Construction of Standard Curve for the Real-Time RT-PCR Assay}

The standard curve for $\alpha 4 \mathrm{GnT}$ constructed by using 10 -fold dilutions of $\alpha 4 \mathrm{GnT}$ cDNA, pcDNAl- $\alpha 4 \mathrm{GnT}$, is shown in Figure 2. The cycle number where the fluorescence reached the detection threshold was defined as $\mathrm{C}_{\mathrm{T}}$, and a strong linear relationship between the $\mathrm{C}_{\mathrm{T}}$ and the log of the amount of the cDNAs was demonstrated. On the basis of the standard curve, we could detect $\alpha 4 \mathrm{GnT}$ cDNA from $6 \times 10^{-2}$ to $2.4 \times 10^{-10} \mu \mathrm{g} / \mathrm{ml}$, corresponding to $1 \times 10^{10}$ to $4 \times$ $10^{1}$ copies $/ \mathrm{ml}$. Thus, the amount of $\alpha 4 \mathrm{GnT}$ transcripts more than 40 copies $/ \mathrm{ml}$ was defined to be positive for the $\alpha 4 \mathrm{GnT}$. Similarly, the standard curve for a housekeeping gene, glyceraldehyde-3-phosphate dehydrogenase (GAPDH) was constructed by using 10-fold dilutions of pCR2.1-GAPDH ranging from $1.2 \times 10^{-2}$ to $1.2 \times 10^{-6} \mu \mathrm{g} / \mathrm{ml}$ (data not shown). With the use of these standard curves, amounts of $\alpha 4 \mathrm{GnT}$ mRNA and GAPDH mRNA were determined, and the relative expression level of $\alpha 4 \mathrm{GnT}$ was defined by multiplying $\alpha 4 \mathrm{GnT}$ :GAPDH mRNA ratios by $1.0 \times 10^{7}$.

\section{Detection of $\alpha 4 G n T$ mRNA in Peripheral Blood Samples Derived from Healthy Volunteers and Patients with Helicobacter pylori-Infected Chronic Active Gastritis}

By using the real-time RT-PCR, expression of $\alpha 4 \mathrm{GnT}$ mRNA in the mononuclear cell fraction of peripheral blood obtained from the healthy volunteers and patients with $H$. pylori-infected chronic active gastritis as well as patients with peptic gastroduodenal ulcers 
was examined (Fig. 3). In 23 healthy volunteers, the transcripts of $\alpha 4 \mathrm{GnT}$ were not detectable in the peripheral blood. With the use of the commercially available blood cell cDNA panels, it was also shown that $\alpha 4 \mathrm{GnT}$ mRNA was not detectable in leukocytes, mononuclear cells (B cells, T cells, and monocytes), resting and activated $\mathrm{CD} 8+$ cells, resting and activated CD4 + cells, resting and activated CD19+ cells, resting CD14+ cell, and activated mononuclear cells. In the patients with chronic active gastritis or peptic gastroduodenal ulcer, however, $\alpha 4 \mathrm{GnT}$ transcripts in the peripheral blood were detected in three (33.3\%) of nine patients with gastritis and in all of four patients with peptic ulcer. It is interesting that the relative amounts of $\alpha 4 \mathrm{GnT}$ mRNA to GAPDH mRNA in the patients with ulcer was shown to be significantly higher than that in the chronic active gastritis (3.156 \pm
0.498 versus $0.406 \pm 0.206$ [mean $\pm \mathrm{sE}$ ]; $p<0.05$, Dunnett's test; Fig. 3), indicating that gastric mucous cells expressing $\alpha 4 \mathrm{GnT}$ could enter the peripheral blood stream through mucosal disruption or ulceration, and the relative amount of $\alpha 4 \mathrm{GnT}$ transcripts in the peripheral blood might reflect the extent of the mucosal damage.

\section{Detection of $\alpha 4 G n T$ mRNA in Peripheral Blood Samples of Patients with Gastric Cancer}

To determine whether $\alpha 4 \mathrm{GnT}$ mRNA was detected in the mononuclear cell fraction of peripheral blood taken from patients with gastric cancer, we performed quantitative analysis of $\alpha 4 \mathrm{GnT}$ mRNA for 37 patients with gastric cancer. The transcripts of $\alpha 4 \mathrm{GnT}$ were detected in $23(62.2 \%)$ of the patients with gastric
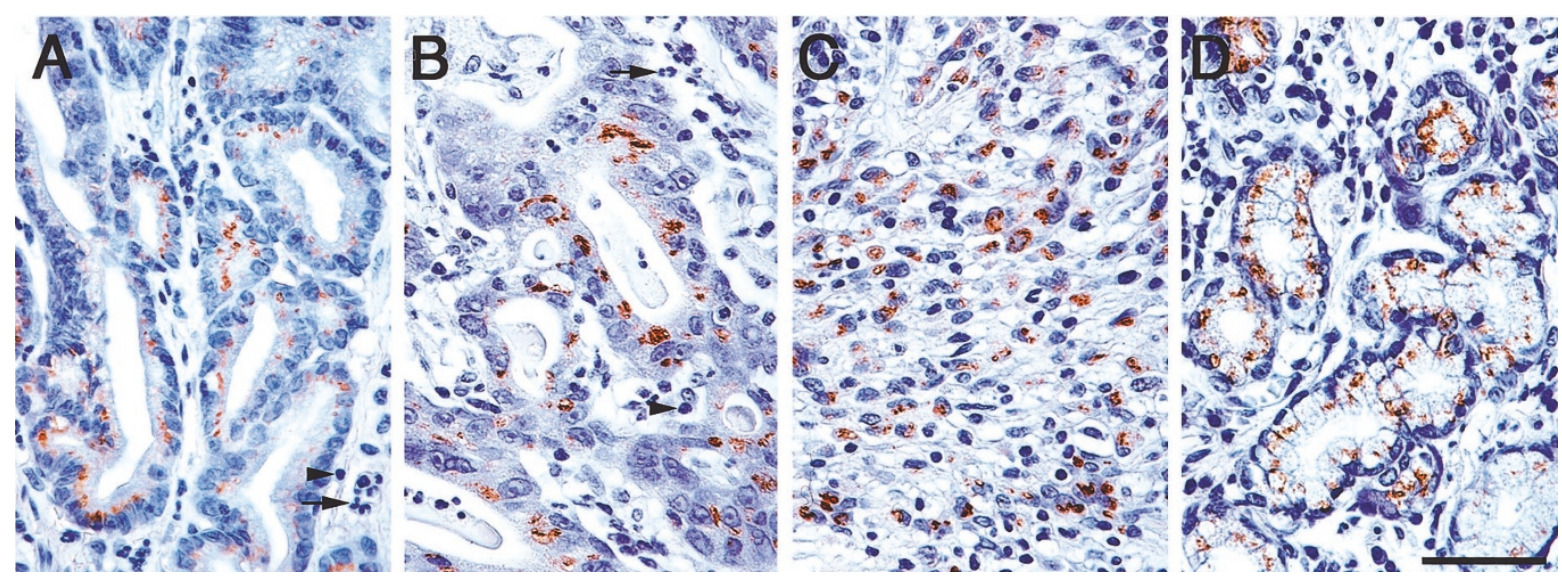

\section{Figure 1.}

Immunohistochemical detection of $\alpha 1,4-N$-acetylglucosaminyltransferase ( $\alpha 4 \mathrm{GnT})$ protein in gastric cancer cells and normal pyloric gland cells. $\alpha 4 \mathrm{GnT}$ is expressed in the Golgi region of gastric cancer cells of intestinal-type carcinoma (A and B) and diffuse-type carcinoma (C). It is also expressed in the Golgi region of normal pyloric gland cells of the stomach (D). Immunohistochemistry with anti- $\alpha 4 \mathrm{GnT}$ antibody I17K. Arrows and arrowhead indicate leukocytes and lymphocytes, respectively. Bar $=50 \mu \mathrm{m}$.

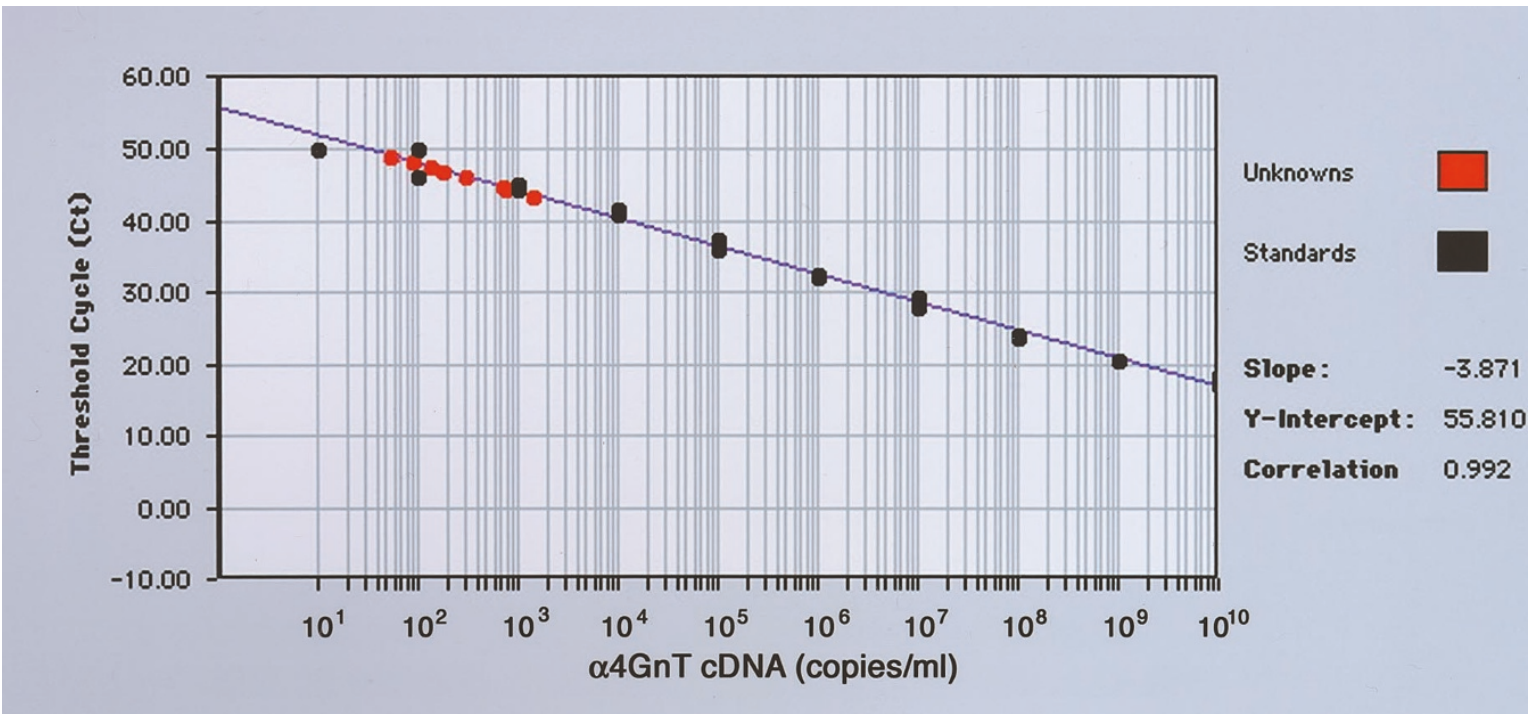

Figure 2.

Standard curve of real-time reverse transcription polymerase chain reaction (RT-PCR) of $\alpha 4 \mathrm{GnT}$ mRNA. A plasmid encoding human $\alpha 4 \mathrm{GnT}$, pcDNAl- $\alpha 4 \mathrm{GnT}$, was serially diluted from $10^{10}$ to $10^{1} \mathrm{copies} / \mathrm{ml}$ and used to construct the standard curve (black dots). Unknowns (red dots) represent patients' samples. 


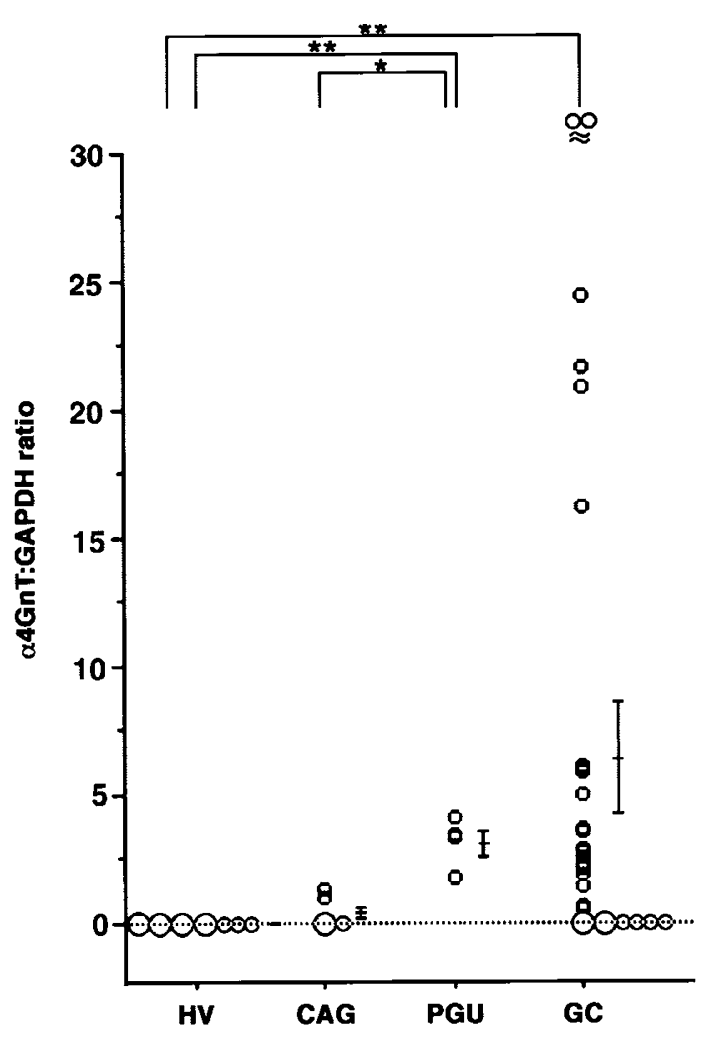

Figure 3.

Expression levels of $\alpha 4 \mathrm{GnT}$ mRNA determined by real-time RT-PCR method in the mononuclear cell fraction of peripheral blood from healthy volunteers and patients with chronic active gastritis, peptic gastroduodenal ulcer, and gastric cancer. Small and large circles indicate one and five people, respectively. $\alpha 4 \mathrm{GnT}$ :glyceraldehyde-3-phosphate dehydrogenase mRNA ratios multiplied by $1.0 \times 10^{7}$ are indicated, and bars indicate mean $\pm \mathrm{SE}$. HV, healthy volunteers; $\mathrm{CAG}$, chronic active gastritis; PGU, peptic gastroduodenal ulcer; GC, gastric cancer; ${ }^{\star} p<0.05 ;{ }^{* \star} p<0.01$ (Dunnett's test).

cancer, and the relative expression level of $\alpha 4 \mathrm{GnT}$ mRNA to GAPDH mRNA in the patients with gastric cancer was $6.461 \pm 2.164$ (mean $\pm \mathrm{SE}$ ), significantly higher than that in the normal volunteer $(p<0.01$, Dunnett's test; Fig. 3). Although the significant differences were not obtained by the Dunnett's test, the expression level of $\alpha 4 \mathrm{GnT}$ in patients with gastric cancer was higher than that in the patients with chronic active gastritis and peptic gastroduodenal ulcer. The sensitivity and specificity of this assay for the detection of gastric cancer are, thus, determined to be 0.622 and 0.806 , respectively.

The expression levels of $\alpha 4 \mathrm{GnT}$ in the peripheral blood taken from the 37 patients with gastric cancer were then evaluated by clinicopathological variables that were determined at the subsequent surgical operation. As shown in Table 1, the amount of $\alpha 4 \mathrm{GnT}$ mRNA was positively correlated with tumor stage, depth of tumor invasion, vessel and lymphatic invasion, and lymph node and distant metastases. In particular, significant correlations were found between the tumor stage I and IV ( $p<0.05$, Dunnett's test) as well as in distant metastasis ( $p=0.0157$, MannWhitney $U$ test). Regarding the histopathological classification of gastric cancer (Laurén, 1965), the $\alpha 4 \mathrm{GnT}$ transcripts were more abundantly detected in the peripheral blood of patients with diffuse-type carcinoma than in those with intestinal-type carcinoma (Table 1).

In 29 patients with gastric cancer, the expression levels of $\alpha 4 \mathrm{GnT}$ mRNA in peripheral blood were compared with the expression level of $\alpha 4 \mathrm{GnT}$ protein determined by the immunohistochemistry of the subsequently resected stomach using the anti- $\alpha 4 \mathrm{GnT}$ antibody I17K as described above (Fig. 4). The transcripts of $\alpha 4 \mathrm{GnT}$ were more abundantly expressed in the peripheral blood of the patients who were positive for $\alpha 4 \mathrm{GnT}$ protein in the gastric cancer cells compared with the patients who were negative for $\alpha 4 \mathrm{GnT}$ protein in the cancer cells with statistical significance (9.505 \pm 3.447 versus $0.696 \pm 0.455$ [mean $\pm \mathrm{SE}$ ]; $p=0.0270$, Mann-Whitney $U$ test). Taking into account that $\alpha 4 \mathrm{GnT}$ is not detectable in the peripheral blood cells including leukocytes, lymphocytes, and monocytes, these combined results suggest that $\alpha 4 \mathrm{GnT}$ mRNA detected in the peripheral blood of the patients with gastric cancer originated from circulating gastric cancer cells. Thus, the real-time RT-PCR method targeted to $\alpha 4 \mathrm{GnT}$ mRNA would allow us to detect such circulating cancer cells.

\section{Detection of $\alpha 4 G n T$ mRNA in the Peripheral Blood of the Patients with Gastric Cancer during the Course of Postsurgical Follow-Up}

To examine the expression level of $\alpha 4 \mathrm{GnT}$ mRNA during the course of postsurgical follow-up, we analyzed the mononuclear cell fraction of the peripheral blood obtained from three patients with gastric cancer by real-time RT-PCR (Table 2). In all of the patients, $\alpha 4 \mathrm{GnT}$ mRNA detected in the peripheral blood before the operation turned out to be negative after the surgical removal of gastric cancer, irrespective of the stages. In a nonrecurred patient with stage II (patient 21), small amounts of $\alpha 4 \mathrm{GnT}$ mRNA comparable with those in the chronic active gastritis were detected 464 days after the operation. In contrast, the significant amounts of $\alpha 4 \mathrm{GnT}$ mRNA were again detected in the recurred patients with stage III (patients 30 and 31) 372 and 362 days after the operation, respectively. These results indicate that the real-time RT-PCR assay targeted to $\alpha 4 \mathrm{GnT}$ might be helpful during the course of postsurgical follow up. Additional studies with larger series will be required to determine the usefulness of this assay for the postsurgical monitoring of gastric cancer.

\section{Comparison of $\alpha 4 G n T$ mRNA with Two Distinct Tumor Markers, CEA and CA19-9}

The results of the quantitative analysis for $\alpha 4 \mathrm{GnT}$ mRNA in peripheral blood of the preoperative patients with gastric cancer were then compared with the serum levels of two distinct tumor markers, CEA and CA19-9, in the same patients. As shown in Table 3, the expression levels of $\alpha 4 \mathrm{GnT}$ mRNA were not correlated with those of either CEA or CA19-9, irrespective of the tumor stages. In addition, it was shown that the sensitivity of $\alpha 4 \mathrm{GnT}$ for the detection of gastric cancer 
Table 1. Correlation of the Expression Level of $\alpha 4 \mathrm{GnT}$ mRNA in the Mononuclear Cell Fraction of Peripheral Blood from Patients with Gastric Cancer with Clinicopathological Variables

\begin{tabular}{|c|c|c|c|}
\hline & $\begin{array}{c}\text { Frequency of } \\
\text { positive patients }\end{array}$ & $\begin{array}{c}\alpha 4 \mathrm{GnT}: \mathrm{GAPDH} \text { ratio } \\
(\text { mean } \pm \mathrm{SE})\end{array}$ & $p$ \\
\hline \multicolumn{4}{|l|}{ Tumor stage } \\
\hline 1 & $11 / 19(57.9 \%)$ & $1.632 \pm 0.492$ & \multirow{4}{*}{$<0.05^{c}$} \\
\hline$\|$ & $2 / 6(33.3 \%)$ & $4.073 \pm 3.548$ & \\
\hline III & $4 / 6(66.7 \%)$ & $14.389 \pm 7.249$ & \\
\hline IV & $6 / 6(100 \%)$ & $16.210 \pm 9.614$ & \\
\hline \multicolumn{4}{|c|}{ Depth of tumor invasion } \\
\hline Intramucosa & $4 / 5(80.0 \%)$ & $1.090 \pm 0.560$ & \multirow{5}{*}{$0.8301^{d}$} \\
\hline Submucosa & $6 / 11(54.5 \%)$ & $2.135 \pm 0.780$ & \\
\hline Proper muscle & $2 / 4(50.0 \%)$ & $6.345 \pm 5.180$ & \\
\hline Subserosa & $4 / 8(50.0 \%)$ & $9.575 \pm 5.760$ & \\
\hline Serosa & $6 / 8(75.0 \%)$ & $13.205 \pm 7.525$ & \\
\hline \multicolumn{4}{|l|}{ Venous invasion } \\
\hline Negative & $12 / 18(66.7)$ & $3.117 \pm 1.351$ & \multirow{2}{*}{$0.7942^{e}$} \\
\hline Positive & $10 / 18(55.6 \%)$ & $10.024 \pm 4.135$ & \\
\hline \multicolumn{4}{|l|}{ Lymphatic invasion } \\
\hline Negative & $7 / 12(58.3 \%)$ & $1.760 \pm 0.681$ & \multirow[t]{2}{*}{$0.3778^{e}$} \\
\hline Positive & $15 / 24(62.5 \%)$ & $8.976 \pm 3.225$ & \\
\hline \multicolumn{4}{|c|}{ Lymph node metastasis } \\
\hline Negative & $11 / 20(55.0 \%)$ & $1.662 \pm 0.475$ & \multirow[t]{2}{*}{$0.0850^{e}$} \\
\hline Positive & $11 / 16(68.8 \%)$ & $12.705 \pm 4.587$ & \\
\hline \multicolumn{4}{|l|}{ Distant metastasis } \\
\hline Negative & $17 / 31(54.8 \%)$ & $4.573 \pm 1.729$ & \multirow[t]{2}{*}{$0.0157^{e}$} \\
\hline Positive & $6 / 6(100 \%)$ & $16.211 \pm 9.615$ & \\
\hline \multicolumn{4}{|l|}{ Histopathology ${ }^{f}$} \\
\hline Intestinal type & $15 / 25(60.0 \%)$ & $5.781 \pm 1.156$ & \multirow[t]{2}{*}{$0.3858^{e}$} \\
\hline Diffuse type & $8 / 12(66.7 \%)$ & $20.671 \pm 5.967$ & \\
\hline
\end{tabular}

${ }^{a}$ The amounts of $\alpha 4 \mathrm{GnT}$ mRNA more than 40 copies $/ \mathrm{ml}$ in a reaction tube are defined as positive.

${ }^{b} \alpha 4 \mathrm{GnT}$ :GAPDH mRNA ratios multiplied by $1.0 \times 10^{7}$ are indicated.

${ }^{c}$ Analyzed by Dunnett's test. Significant difference was found between stage I and IV.

${ }^{a}$ Analyzed by Kruskal-Wallis test.

${ }^{e}$ Analyzed by Mann-Whitney $U$ test.

${ }^{f}$ The Laurén classification.

seemed to be superior to that of CEA and CA19-9, ie, $\alpha 4 \mathrm{GnT}$ was detected in $23(62.2 \%)$ of 37 patients, whereas CEA and CA19-9 were merely detected in 11 (29.7\%) and $3(8.1 \%)$ patients, respectively. It is noteworthy that all patients with stage IV were positive for $\alpha 4 \mathrm{GnT}$ transcripts, whereas CEA and CA19-9 were not highly elevated in some of these patients.

\section{Detection of $\alpha 4 G n T$ mRNA in Peripheral Blood Samples of Patients with Cancer Other Than Gastric Cancer}

The expression levels of $\alpha 4 \mathrm{GnT}$ mRNA in mononuclear cell fraction of the peripheral blood taken from patients with cancers other than gastric cancer were also measured by the real-time RT-PCR method. As shown in Table 4, $\alpha 4$ GnT mRNA was not detectable in the patients with esophageal cancer, lung cancer, breast cancer, and uterine cancer. Small amounts of $\alpha 4 \mathrm{GnT}$ mRNA comparable with those of chronic active gastritis were detected in two $(20 \%)$ and one $(25 \%)$ colorectal and liver cancer patients, respectively. By contrast, significant amounts of $\alpha 4 \mathrm{GnT}$ mRNA comparable with those of gastric cancer were detected in all of the patients with pancreatic cancer and carci-

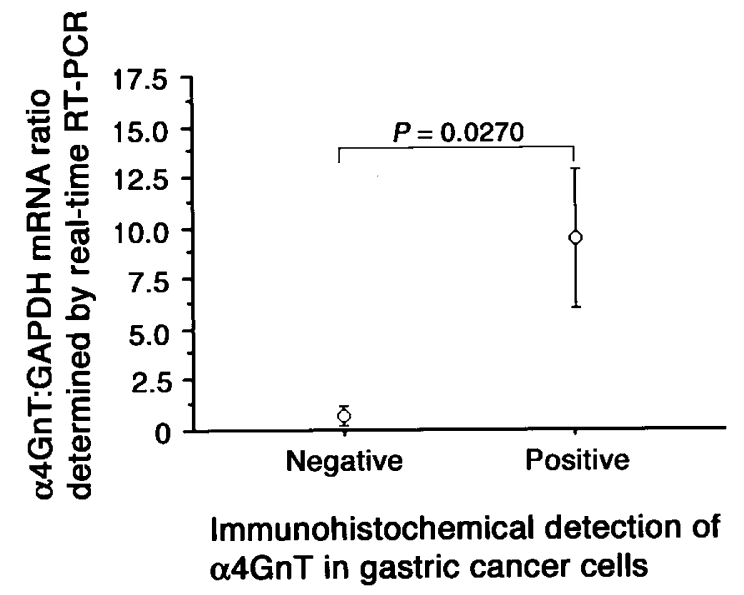

Figure 4.

Correlation of the expression levels of $\alpha 4 G n T$ mRNA detected in the peripheral blood by real-time RT-PCR and the expression of $\alpha 4 \mathrm{GnT}$ detected by using anti- $\alpha 4 \mathrm{GnT}$ antibody I17K in the subsequently resected gastric cancer. The expression level of $\alpha 4 \mathrm{GnT}$ mRNA detected in the peripheral blood from the patients whose cancer cells express $\alpha 4 \mathrm{GnT}$ is significantly higher than that from the patients whose cancer cells do not express $\alpha 4 \mathrm{GnT}$ ( $p=0.0270$, Mann-Whitney $U$ test). 
Table 2. Expression Level of $\alpha 4 \mathrm{GnT}$ mRNA in the Mononuclear Cell Fraction of Peripheral Blood from Patients with Gastric Cancer during Postsurgical Follow-up

\begin{tabular}{|c|c|c|c|c|}
\hline \multicolumn{2}{|c|}{ Patient Stage } & $\begin{array}{c}\text { Days } \\
\text { post- } \\
\text { surgery }\end{array}$ & $\underset{\text { ratio }^{a}}{\alpha 4 \mathrm{GnT}: \mathrm{GAPDH}}$ & Outcome \\
\hline \multirow[t]{6}{*}{21} & II & -1 & 21.65 & \\
\hline & & 1 & 0 & \\
\hline & & 7 & 0 & \\
\hline & & 10 & 0 & \\
\hline & & 21 & 0 & \\
\hline & & 464 & 0.9925 & No recurrence \\
\hline \multirow[t]{8}{*}{30} & III & -4 & 44.25 & \\
\hline & & 7 & 0 & \\
\hline & & 14 & 0 & \\
\hline & & 24 & 0 & \\
\hline & & 49 & 0 & \\
\hline & & 104 & 0 & \\
\hline & & 372 & 2.636 & \\
\hline & & 428 & & Died \\
\hline \multirow[t]{6}{*}{31} & III & -1 & 16.215 & \\
\hline & & 14 & 0 & \\
\hline & & 25 & 0 & \\
\hline & & 362 & 7.883 & \\
\hline & & 485 & 8.365 & \\
\hline & & 508 & & Died \\
\hline
\end{tabular}

${ }^{a} \alpha 4$ GnT:GAPDH mRNA ratios multiplied by $1.0 \times 10^{7}$ are indicated.

Table 3. Comparison of Frequencies of Positive Patients for $\alpha 4$ GnT mRNA, CEA, and CA19-9 Detected in Peripheral Blood of Patients with Gastric Cancer

\begin{tabular}{lccc}
\hline $\begin{array}{c}\text { Tumor } \\
\text { stage }\end{array}$ & $\begin{array}{c}\alpha 4 \mathrm{GnT} \text { mRNA } \\
(>40 \\
\text { copies/ml) }\end{array}$ & $\begin{array}{c}\text { CEA }(>2.5 \\
\mathrm{ng} / \mathrm{ml})\end{array}$ & $\begin{array}{c}\text { CA19-9 } \\
37 \mathrm{U} / \mathrm{ml})\end{array}$ \\
\hline I & $11 / 19(57.9 \%)$ & $3 / 19(15.8 \%)$ & $0 / 19(0 \%)$ \\
II & $2 / 6(33.3 \%)$ & $2 / 6(33.3 \%)$ & $0 / 6(0 \%)$ \\
III & $4 / 6(66.7 \%)$ & $2 / 6(33.3 \%)$ & $0 / 6(0 \%)$ \\
IV & $6 / 6(100 \%)$ & $4 / 6(66.7 \%)$ & $3 / 6(50.0 \%)$ \\
Total & $23 / 37(62.2 \%)$ & $11 / 37(29.7 \%)$ & $3 / 37(8.1 \%)$ \\
\hline
\end{tabular}

noma of the papilla vater as well as in three (60\%) patients with bile duct cancer, suggesting the possible usefulness of this assay for the detection of pancreatic and bile duct cancers as well as papilla vater cancer.

\section{Discussion}

$\alpha 4 \mathrm{GnT}$ is a glycosyltransferase responsible for the biosynthesis of $\mathrm{GlcNAc} \alpha 1 \rightarrow 4 \mathrm{Gal} \beta \rightarrow \mathrm{R}$ structures characteristic for the gastric gland mucous cell-type mucin (Nakayama, 2002). In the present study, we first demonstrated that this enzyme is frequently expressed in the gastric cancer cells, but not in peripheral blood cells, using immunohistochemistry with a specific antibody for $\alpha 4 \mathrm{GnT}$, I17K (see Fig. 1). By using real-time RT-PCR targeted to the $\alpha 4 \mathrm{GnT}$ mRNA, we could detect the transcripts of $\alpha 4 \mathrm{GnT}$ in the
Table 4. Detection of $\alpha 4 \mathrm{GnT}$ mRNA by Real-Time RT-PCR Method in the Mononuclear Cell Fraction of Peripheral Blood from Patients with Cancer Other Than Gastric Cancer

\begin{tabular}{lcc}
\hline $\begin{array}{c}\text { Cancer } \\
\text { location }\end{array}$ & $\begin{array}{c}\text { Frequency of } \\
\text { positive patients }\end{array}$ & $\begin{array}{c}\alpha 4 \mathrm{GnT} \text { GAPDH } \\
\text { ratio }^{b} \text { (mean } \pm \mathrm{SE} \text { ) }\end{array}$ \\
\hline Esophagus & $0 / 1(0 \%)$ & $0 \pm 0$ \\
Lung & $0 / 2(0 \%)$ & $0 \pm 0$ \\
Breast & $0 / 1(0 \%)$ & $0 \pm 0$ \\
Uterus & $0 / 1(0 \%)$ & $0 \pm 0$ \\
Colorectum & $2 / 10(20.0 \%)$ & $0.565 \pm 0.380$ \\
Liver & $1 / 4(25.0 \%)$ & $0.174 \pm 0.174$ \\
Pancreas & $4 / 4(100 \%)$ & $15.220 \pm 11.220$ \\
Papilla vater & $1 / 1(100 \%)$ & $4.145 \pm 0$ \\
Bile duct & $3 / 5(60.0 \%)$ & $2.994 \pm 1.950$ \\
\hline
\end{tabular}

${ }^{a}$ The amounts of $\alpha 4 \mathrm{GnT}$ mRNA more than 40 copies $/ \mathrm{ml}$ in a reaction tube are defined as positive.

${ }^{b} \alpha 4$ GnT:GAPDH mRNA ratios multiplied by $1.0 \times 10^{7}$ are indicated.

mononuclear cell fraction of peripheral blood isolated from patients with gastric cancer but not from healthy volunteers, and the expression level of $\alpha 4 \mathrm{GnT}$ transcripts was increased in association with tumor progression, including tumor stage, depth of the tumor invasion, vessel invasion, and metastases. By combining the results obtained by immunohistochemistry and real-time RT-PCR, we also demonstrated that the expression level of $\alpha 4 \mathrm{GnT}$ mRNA in the peripheral blood is clearly associated with the expression of $\alpha 4 \mathrm{GnT}$ protein in gastric cancer cells (see Fig. 4). Moreover, it was also shown that $\alpha 4 \mathrm{GnT}$ mRNA disappears from peripheral blood after the surgical removal of gastric cancer (see Table 2). Although the circulating tumor cells have not been identified directly in this study, these combined results strongly suggest that $\alpha 4 \mathrm{GnT}$ mRNA detected in peripheral blood of the patients with gastric cancer originated from the circulating cancer cells. It would be a challenge to identify a small number of the circulating tumor cells in the peripheral blood by using morphological techniques such as immunocytochemistry using anti- $\alpha 4 \mathrm{GnT}$ antibody or HIK1083 antibody directed to the GlcNAc $\alpha 1 \rightarrow \mathrm{Gal} \beta \rightarrow \mathrm{R}$ residue.

Among the serum tumor markers, CEA and CA19-9 are most widely used for the screening and monitoring of gastric cancer (Pectasides et al, 1997). However, these biomarkers have limitation for early detection of gastric cancer, because both markers tend to be elevated in advanced cancers than in early stages of the cancers. In fact, the present study revealed that in 19 patients with stage I gastric cancer, CEA was elevated only in 15.8\% of the patients, and no patients were positive for CA19-9 (see Table 3). By contrast, the transcripts of $\alpha 4 \mathrm{GnT}$ were detected in $57.9 \%$ of the same 19 patients with stage I gastric cancer. These results indicate that for early detection of gastric cancer, the real-time RT-PCR assay targeted to the $\alpha 4 \mathrm{GnT}$ mRNA is much more sensitive than the immunoassay for CEA or CA19-9. CA72-4 is a tumor assay that detects the sialyl $\mathrm{Tn}$ antigen NeuAc $\alpha 2 \rightarrow 6$ GalNAc $\alpha 1 \rightarrow$ Ser/Thr (Guadagni et al, 1996). 
Immunohistochemical studies demonstrated that this carbohydrate antigen is highly expressed in gastric cancer cells (David et al, 1992; Victorzon et al, 1996). However, Kodama et al (1995) reported that the positive rates of CA72-4 in the sera of 100 patients with gastric cancer are $2.3 \%$ in early stage and $37.5 \%$ in the advanced stage. Future studies will be of significance to compare the clinical utility of $\alpha 4 \mathrm{GnT}$ mRNA with CA72-4.

Extensive studies have been carried out to detect circulating tumor cells using RT-PCR method targeted to tissue- or epithelial cell-specific molecules such as CEA and CK19 for gastric cancer (Aihara et al, 1997; Majima et al, 2000; Nishida et al, 2000; Piva et al, 2000; Yeh et al, 1998), CEA and mutated p53 gene for colorectal cancer (Guadagni et al, 2001; Jonas et al, 1996; Khan et al, 2000; Piva et al, 2000), human tissue kallikrein 2 for prostatic cancer (Kawakami et al, 1997), uroplakin II for urothelial cancer (Lu et al, 2000), and GM2/GD2 synthase for neuroblastoma (Hoon et al, 2001). Most of these studies demonstrated that the molecular detection by RT-PCR is feasible for the identification of circulating tumor cells in the peripheral blood. However, these assays were based on the ordinary RT-PCR method and thus did not accurately quantify the targeted molecules. By contrast, the recently introduced real-time $\mathrm{RT}$-PCR technology made it possible to quantitatively analyze the circulating cancer cells using tissue-specific molecules such as prostate-specific antigen for prostate cancer (Straub et al, 2001) and MUC1 mucin for breast cancer (de Cremoux et al, 2000).

For gastric cancer, it was shown that gastric gland mucous cell-type mucins that have $\mathrm{GlcNAc} \alpha 1 \rightarrow \mathrm{Gal} \beta \rightarrow \mathrm{R}$ residues formed by $\alpha 4 \mathrm{GnT}$ are frequently expressed in the tumor cells but not in peripheral blood cells (Nakamura et al, 1998). In the present study, we thus chose $\alpha 4 \mathrm{GnT}$ mRNA as a tissue-specific molecule of gastric cancer for the real-time RT-PCR assay. Absence of $\alpha 4 \mathrm{GnT}$ mRNA in the peripheral blood cells was further verified using the blood cell cDNA panels. In addition to the gastric cancer, the gastric gland mucous cell-type mucin is shown to be frequently expressed in cancer cells derived from pancreas and biliary tract (Nakamura et al, 1998), suggesting that the real-time RT-PCR assay targeted to $\alpha 4 \mathrm{GnT}$ would be useful for the detection of the pancreaticobiliary tract cancer. In fact, we found that significant amounts of the $\alpha 4 \mathrm{GnT}$ mRNA can be detected in the peripheral blood isolated from the patients with pancreatic cancer, papilla vater cancer, and biliary tract cancer (see Table 4).

It was demonstrated that the real-time RT-PCR assay used in this study could detect $\alpha 4 \mathrm{GnT}$ mRNA in as low as 40 copies $/ \mathrm{ml}$ in a reaction tube. On the basis of this result, the minimum copy numbers of $\alpha 4 \mathrm{GnT}$ mRNA in the peripheral blood detectable for this assay were calculated to be more than 1.6 copies in $5 \mathrm{ml}$ of the peripheral blood containing approximately $2.0 \times$ $10^{7}$ to $5.0 \times 10^{7}$ mononuclear blood cells. Because the actual copy numbers of $\alpha 4 \mathrm{GnT}$ mRNA in gastric cancer cells seem to be variable, it is difficult to estimate the minimum numbers of the cancer cells detected for this assay. However the frequent detection of $\alpha 4 \mathrm{GnT}$ mRNA in the mononuclear cell fraction of the peripheral blood of the patients with stage I gastric cancer suggests that the gastric cancer cells expressing $\alpha 4 \mathrm{GnT}$ mRNA are actually circulating in peripheral blood even in early stages of gastric cancer. Because the $\mathrm{E}$ - and/or P-selectin-mediated cell adhesion of cancer cells to the endothelial cells in remote organs is one of the critical events for metastatic colonization of the cancer cells (Fukuda, 1996; Hakomori, 1996; Nicolson, 1988), the detection of circulating cancer cells does not necessarily indicate the presence of metastasis. However, as shown in this study, the detection of circulating cancer cells in early stages of the gastric cancer indicates that (micro)metastases could already be occurring in the patients when the gastric cancer cells are still limited to the gastric mucosa or submucosa. In fact, Seto et al (2001) reported that the frequency of lymph node metastases of early gastric cancer is merely $8.9 \%$. In addition, the strong correlation between the expression level of $\alpha 4 \mathrm{GnT}$ mRNA and clinicopathological variables including the tumor stage suggests that more cancer cells are released to the blood stream when gastric cancer advances.

In the present study, the expression level of $\alpha 4 \mathrm{GnT}$ mRNA in the mononuclear cell fraction of peripheral blood from the patients with $\mathrm{H}$. pylori-infected chronic active gastritis and peptic gastroduodenal ulcer was also evaluated. Three of nine patients with chronic active gastritis and all of four patients with peptic gastroduodenal ulcer were actually positive for this assay. Although the significant difference was not obtained between the patients with gastric cancer and patients with these benign gastric disorders, mean value of $\alpha 4 \mathrm{GnT}$ mRNA detected in chronic active gastritis and peptic gastroduodenal ulcer was lower than that in gastric cancer (see Fig. 3). By contrast, we have also shown that $\alpha 4 \mathrm{GnT}$ mRNA was not detectable in the mononuclear cell fraction of peripheral blood isolated from healthy individuals. These combined results suggest that gastric gland mucous cells expressing $\alpha 4 \mathrm{GnT}$ are not released into the peripheral blood under the normal conditions. However, once the mucosal disruption such as inflammation and ulceration occurs in gastric mucosa, the gastric gland mucous cells enter the blood stream through the injured sites. These results are consistent with our previous report that extensive biopsy of the gastric mucosa allows the gastric epithelial cells to enter the peripheral blood (Shimizu et al, 2000). Thus, detection of $\alpha 4 \mathrm{GnT}$ mRNA in peripheral blood does not always exclude the possibility of benign mucosal injuries including chronic active gastritis and peptic gastroduodenal ulcer. However, this assay is noninvasive and sensitive enough for the early detection of gastric cancer compared with other ordinary tumor markers such as CEA and CA19-9. Therefore, we conclude that the real-time RT-PCR targeted to $\alpha 4 \mathrm{GnT}$ mRNA will be useful for the screening of gastric cancer. 


\section{Materials and Methods}

\section{Patients and Samples}

The present study involved 37 patients with gastric cancer (23 men and 14 women; age ranges, 46-97 years) and 29 patients with cancer other than gastric cancer (18 men and 11 women; age ranges, 40-81 years) including 10 cases of colorectal cancer; 5 cases of bile duct cancer; 4 cases of pancreatic cancer; 4 cases of hepatoma; 2 cases of lung cancer; and 1 case each of esophageal cancer, papilla vater cancer, breast cancer, and uterine cancer. These patients except for one with advanced gastric cancer with peritoneal dissemination subsequently underwent surgical operation for the removal of primary tumor at Shinshu University Hospital, Matsumoto, Japan, within 4 weeks in average after the diagnosis was established. In addition, 9 patients $(7$ males and 2 females; age ranges, 30-58 years) with $H$. pyloriinfected chronic active gastritis, 4 patients ( 2 men and 2 women; age ranges, 66-83) with peptic gastroduodenal ulcer, and 23 healthy volunteers (14 men and 9 women; age ranges, 23-57 years) were enrolled in this study. Status of $H$. pylori infection was serologically determined using a PirikaplateG Helicobacter kit (Fujirebio, Tokyo, Japan) as described previously (Misawa et al, 1998), and the healthy volunteers, negative for $H$. pylori infection, were chosen. Histopathology of gastric cancer was evaluated on the basis of the Laurén (1965) classification, and tumor stage was categorized according to the histological tumor-nodemetastasis classification system (Hayashi et al, 2000).

The peripheral blood samples were taken from these patients as well as healthy volunteers. In the patients with cancer, the blood samples were collected before surgical resection of the primary tumor, but the samples during postsurgical follow-up were also collected in three of the patients with gastric cancer. When the patients underwent endoscopic biopsy of the gastric mucosa, the blood samples were taken at least 2 weeks after the biopsy. In addition, human QUICK-Clone cDNA of leukocytes pooled from 550 male/female white individuals as well as human blood fractions multiple tissue cDNA (MTC) panel of the first-strand cDNA prepared from T cells, B cells, and monocytes were purchased from Clontech (Palo Alto, California). The MTC panel is composed of mononuclear cells ( $B$ cells, $T$ cells, and monocytes) pooled from 50 male/female white individuals, resting CD8 + cells pooled from 33 male/female white individuals, resting CD4+ cells pooled from 20 male/female white individuals, resting CD14+ cells pooled from 36 male/female white individuals, resting CD19+ cells pooled from 34 male/female white individuals, CD19+ cells activated with pokeweed mitogen pooled from 4 male/female white individuals, mononuclear cells activated with pokeweed mitogen and concanavalin $\mathrm{A}$ pooled from 4 male/female white individuals, CD4+ cells activated with concanavalin A pooled from 12 male/female white individuals, and CD8 cells activated with $\mathrm{PHA}$ pooled from 8 male/female white individuals.
These samples were analyzed by a real-time quantitative RT-PCR assay. This study was approved by the institutional review board of the Shinshu University School of Medicine, Matsumoto, Japan, and written informed consent was obtained from all of the patients and healthy volunteers at Shinshu University Hospital before the study.

\section{Immunohistochemisty for $\alpha \mathbf{4 G n T}$}

For detecting $\alpha 4 \mathrm{GnT}$ in the gastric cancer cells, 29 gastrectomies for gastric cancer were further subjected to immunohistochemistry with monospecific anti- $\alpha 4$ GnT polyclonal antibodies I17K using a Super Sensitive detection kit (BioGenex Laboratories, San Romon, California) as described previously (Zhang et al, 2001). Briefly, deparaffinized tissue sections sliced into $3-\mu \mathrm{m}$ thickness were treated with $0.3 \% \mathrm{H}_{2} \mathrm{O}_{2}$ in methanol and then blocked with $1 \%$ normal goat serum in Tris-buffered saline. The sections were incubated with $117 \mathrm{~K}$ antibody for 1.5 hours. After the sections were washed with Tris-buffered saline, they were incubated with biotinylated anti-rabbit IgG and then horseradish peroxidase-labeled streptavidin. The peroxidase reaction was developed with a diaminobenzidine $/ \mathrm{H}_{2} \mathrm{O}_{2}$ solution, and counterstaining was performed with hematoxylin. In control experiments performed by replacing the primary antibody with preimmune serum or omitting the primary antibody from the staining procedure, no specific staining was found. Tissue specimens containing more than $5 \%$ positively stained cancer cells were defined as positive, and others were classified as negative according to the criteria as described before (Machida et al, 2001).

\section{RNA Extraction and CDNA Synthesis}

Five milliliters of the peripheral blood anticoagulated with EDTA was collected and layered on $3 \mathrm{ml}$ of Lymphprep (Nycomed Pharma, Oslo, Norway) in a $15-\mathrm{ml}$ polypropylene tube. The tube was centrifuged at $2000 \times g$ for 30 minutes at $20^{\circ} \mathrm{C}$. The mononuclear cell fraction was transferred to a new tube, resuspended in $5 \mathrm{ml}$ of phosphate-buffered saline, and then centrifuged at $3000 \times g$ for 5 minutes. Total RNA was isolated from the pellet according to the acid guanidine thiocyanate-chloroform extraction method (Chomczynski and Sacchi, 1987) using ISOGEN-LS (Nippon Gene, Tokyo, Japan) and then incubated with $20 \mu \mathrm{l}$ of a DNase I solution containing RNase inhibitor (Promega, Madison, Wisconsin) at $37^{\circ} \mathrm{C}$ for 10 minutes.

After inactivation of the DNase I by heating, reverse transcription of the total RNA extracted from the peripheral blood was performed in a final volume of 20 $\mu \mathrm{l}$ containing $10 \mu \mathrm{l}$ of the DNase I-treated RNA, $2 \mu \mathrm{l}$ of $5 \times$ first strand buffer, $2 \mu \mathrm{l}$ of $2 \mathrm{~mm}$ dNTPs, $0.2 \mu \mathrm{l}$ of $0.1 \mathrm{M}$ dithiothreitol, $1 \mu \mathrm{l}$ of RNase inhibitor (Promega), $0.5 \mu \mathrm{l}$ of M-MLV (Life Technologies, Gaithersburg, Maryland), and $1 \mu \mathrm{l}$ of $0.5 \mathrm{mg} / \mathrm{ml}$ oligo(dT) $)_{15}$ primer (Promega) at $42^{\circ} \mathrm{C}$ for 60 minutes. These samples 
were kept at $-80^{\circ} \mathrm{C}$ until the real-time quantitative RT-PCR analysis.

\section{Real-Time Quantitative RT-PCR}

The quantitation of $\alpha 4 \mathrm{GnT}$ mRNA levels in the peripheral blood taken from the patients as well as healthy volunteers was performed using an ABI PRISM 7700 Sequence Detection System (PE Applied Biosystems, Foster City, California) based on the continuous optical monitoring of the progress of a fluorogenic PCR (Heid et al, 1996). In addition, the human blood cell cDNA panels including leukocytes, T cells, B cells, and monocytes purchased from Clontech were subjected to this assay. On the basis of the published sequence of human $\alpha 4 \mathrm{GnT}$ (Nakayama et al, 1999), specific primer pair and probe were designed with the aid of the Primer Express program (PE Applied Biosystems). Forward and reverse primers for human $\alpha 4 \mathrm{GnT}$ were 5'-GTITCCTCTTCCCTITGGATATGA-3' (nucleotides 340 to 364), and 5'-TGCCACCGTATITCCAGATGA-3' (nucleotides 490 to 470), respectively. These primers hybridized to different exons of the $\alpha 4 \mathrm{GnT}$ gene. The TaqMan probe spanning the exonexon junction was synthesized to be 5'ACAATCAAATCAACGCCAGCGCAGA-3' (nucleotides 401 to 425 ) by PE Applied Biosystems, and it carried 5'-FAM (6-carboxyfluorescein) reporter label and 3'TAMURA (6-carboxy-N,N,N',N'-tetramethylrhodamine) quencher group. A relative standard curve representing 10 -fold dilutions of a human $\alpha 4 \mathrm{GnT}$ cDNA (pcDNAl- $\alpha 4 \mathrm{GnT})$ ranging from $6 \times 10^{-2}$ to $6 \times 10^{-11}$ $\mu \mathrm{g} / \mathrm{ml}$ was used for linear regression analysis of the patients' samples. PCR was carried out in $50 \mu \mathrm{l}$ of reaction mixture containing $3 \mu$ l of the reverse transcription reaction, $1 \times$ Universal PCR Master Mix (PE Applied Biosystems), 900 nм of each primer, and 250 nM of the TaqMan probe.

For normalizing the expression level of $\alpha 4 \mathrm{GnT}$ mRNA, GAPDH was also quantitatively analyzed in the same reactions. Thus, a partial cDNA of GAPDH was amplified from peripheral blood cells using a specific primer set for GAPDH (PE Applied Biosystems) and then subcloned into pCR2.1 (Invitrogen, San Diego, California). Ten-fold dilutions of the resultant vector, pCR2.1-GAPDH ranging from $1.2 \times 10^{-2}$ to $1.2 \times$ $10^{-6} \mu \mathrm{g} / \mathrm{ml}$, were used to construct a relative standard curve for GAPDH. The PCR mixture was basically the same as that of $\alpha 4 \mathrm{GnT}$ except for $200 \mathrm{~nm} \mathrm{GAPDH}-$ specific TaqMan probe carrying $5^{\prime}-\mathrm{VIC}$ reporter label and 3'-TAMURA quencher group, and $500 \mathrm{~nm}$ of the specific primer for GAPDH purchased from PE Applied Biosystems.

These samples were placed in the ABI PRISM 7700 Sequence Analyzer and preheated at $95^{\circ} \mathrm{C}$ for 10 minutes, amplified for 50 cycles of $95^{\circ} \mathrm{C}$ for $15 \mathrm{sec}-$ onds, followed by $60^{\circ} \mathrm{C}$ for 1 minute. The relative expression level of $\alpha 4 \mathrm{GnT}$ was defined by multiplying $\alpha 4$ GnT:GAPDH mRNA ratios by $1.0 \times 10^{7}$. The assays were performed in duplicate, and mean values of the two experiments were indicated.

\section{Enzyme Immunoassay of CEA and CA19-9 in Patients' Serum}

Expression levels of CEA in serum obtained from the 37 patients with gastric cancer before surgery were evaluated by enzyme immunoassay using CEA - Dainapack kit (Dainabot, Tokyo, Japan) with $2.5 \mathrm{ng} / \mathrm{ml}$ for cut-off value. In parallel, serum level of CA19-9 was also examined using an AXSYM CA19-9 - Dainapack kit (Dainabot) with $37 \mathrm{U} / \mathrm{ml}$ for cutoff value.

\section{Statistical Analysis}

Statistical analyses of the comparison between two independent groups were carried out using by MannWhitney $U$ test. Similarly, the comparison among more than three groups was performed by use of KruskalWallis test, followed by Dunnett's test. All of the statistical analyses were performed using StatVeiw 5.0 software (Abacus Concepts, Berkeley, California), and $P$ values $<0.05$ were considered to be statistically significant.

\section{Acknowledgements}

We thank Drs. Kosei Nakajima, Kazuyoshi Yamauchi, and Eiko Hidaka for valuable discussion during this study, Drs. Kazuhiko Ishihara and Kyoko Hotta for the generous gift of HIK1083 antibody, and Dr. Edgar Ong for critical reading of the manuscript.

\section{References}

Aihara T, Noguchi S, Ishikawa O, Furukawa H, Hiratsuka M, Ohigashi H, Nakamori S, Monden M, and Imaoka S (1997). Detection of pancreatic and gastric cancer cells in peripheral and portal blood by amplification of keratin 19 mRNA with reverse transcriptase-polymerase chain reaction. Int $\mathrm{J}$ Cancer 72:408-411.

Boku T, Nakane Y, Minoura T, Takada H, Yamamura M, Hioki K, and Yamamoto M (1990). Prognostic significance of serosal invasion and free intraperitoneal cancer cells in gastric cancer. Br J Surg 77:436-439.

Chomczynski P and Sacchi N (1987). Single-step method of RNA isolation by acid guanidinium thiocyanate-phenolchloroform extraction. Anal Biochem 162:156-159.

David L, Nesland JM, Clausen H, Carneiro F, and SobrinhoSimoes M (1992). Simple mucin-type carbohydrate antigens ( $T n$, sialosyl-Tn and $T$ ) in gastric mucosa, carcinomas and metastases. APMIS Suppl 27:162-172.

de Cremoux P, Extra JM, Denis MG, Pierga JY, Bourstyn E, Nos C, Clough KB, Boudou E, Martin EC, Muller A, Pouillart $P$, and Magdelenat $H$ (2000). Detection of MUC1-expressing mammary carcinoma cells in the peripheral blood of breast cancer patients by real-time polymerase chain reaction. Clin Cancer Res 6:3117-3122.

Fukuda M (1996). Possible roles of tumor-associated carbohydrate antigens. Cancer Res 56:2237-2244.

Guadagni F, Kantor J, Aloe S, Carone MD, Spila A, D'Alessandro R, Abbolito MR, Cosimelli M, Graziano F, Carboni F, Carlini S, Perri P, Sciarretta F, Greiner JW, Kashmiri SV, Steinberg SM, Roselli M, and Schlom J (2001). Detection of blood-borne cells in colorectal cancer patients 
by nested reverse transcription-polymerase chain reaction for carcinoembryonic antigen messenger RNA: Longitudinal analyses and demonstration of its potential importance as an adjunct to multiple serum markers. Cancer Res 61:25232532.

Guadagni F, Roselli M, Cosimelli M, Spila A, Cavaliere F, Tedesco M, Arcuri R, Abbolito MR, Casale V, Pericoli MN, Vecchione A, Casciani CU, Greiner JW, and Schlom J (1996). Correlation between tumor-associated glycoprotein $72 \mathrm{mu}-$ cin levels in tumor and serum of colorectal patients as measured by the quantitative CA 72-4 immunoassay. Cancer Res 56:5293-5298.

Hakomori S (1996). Tumor malignancy defined by aberrant glycosylation and sphingo(glyco)lipid metabolism. Cancer Res 56:5309-5318.

Hayashi H, Ochiai T, Suzuki T, Shimada H, Hori S, Takeda A, and Miyazawa $Y$ (2000). Superiority of a new UICC-TNM staging system for gastric carcinoma. Surgery 127:129-135.

Heid CA, Stevens J, Livak KJ, and Williams PM (1996). Real time quantitative PCR. Genome Res 6:986-994.

Hoon DS, Kuo CT, Wen S, Wang H, Metelitsa L, Reynolds CP, and Seeger RC (2001). Ganglioside GM2/GD2 synthetase mRNA is a marker for detection of infrequent neuroblastoma cells in bone marrow. Am J Pathol 159:493-500.

Ishihara K, Kurihara M, Goso Y, Urata T, Ota H, Katsuyama T, and Hotta K (1996). Peripheral $\alpha$-linked N-acetylglucosamine on the carbohydrate moiety of mucin derived from mammalian gastric gland mucous cells: Epitope recognized by a newly characterized monoclonal antibody. Biochem J 318: 409-416.

Jonas S, Windeatt S, O-Boateng A, Fordy C, and Allen-Mersh TG (1996). Identification of carcinoembryonic antigenproducing cells circulating in the blood of patients with colorectal carcinoma by reverse transcriptase polymerase chain reaction. Gut 39:717-721.

Jung R, Kruger W, Hosch S, Holweg M, Kroger N, Gutensohn K, Wagener C, Neumaier M, and Zander AR (1998). Specificity of reverse transcriptase polymerase chain reaction assays designed for the detection of circulating cancer cells is influenced by cytokines in vivo and in vitro. $\mathrm{Br} \mathrm{J}$ Cancer 78:1194-1198.

Kawakami M, Okaneya T, Furihata K, Nishizawa O, and Katsuyama T (1997). Detection of prostate cancer cells circulating in peripheral blood by reverse transcription-PCR for hKLK2. Cancer Res 57:4167-4170.

Khan ZA, Jonas SK, Le-Marer N, Patel H, Wharton $R Q$, Tarragona A, Ivison A, and Allen-Mersh TG (2000). p53 mutations in primary and metastatic tumors and circulating tumor cells from colorectal carcinoma patients. Clin Cancer Res 6:3499-3504.

Kodama I, Koufuji K, Kawabata S, Tetsu S, Tsuji Y, Takeda J, and Kakegawa T (1995). The clinical efficacy of CA 72-4 as serum marker for gastric cancer in comparison with CA19-9 and CEA. Int Surg 80:45-48.

Laurén T (1965). The two histologic main types of gastric carcinoma. Acta Pathol Microbiol Scand 64:34.

Lu JJ, Kakehi Y, Takahashi T, Wu XX, Yuasa T, Yoshiki T, Okada Y, Terachi T, and Ogawa O (2000). Detection of circulating cancer cells by reverse transcription-polymerase chain reaction for uroplakin II in peripheral blood of patients with urothelial cancer. Clin Cancer Res 6:3166-3171.
Machida E, Nakayama J, Amano J, and Fukuda M (2001). Clinicopathological significance of core $2 \beta 1,6-\mathrm{N}$ acetylglucosaminyltransferase messenger RNA expressed in the pulmonary adenocarcinoma determined by in situ hybridization. Cancer Res 61:2226-2231.

Majima T, Ichikura T, Takayama E, Chochi K, and Mochizuki H (2000). Detecting circulating cancer cells using reverse transcriptase-polymerase chain reaction for cytokeratin mRNA in peripheral blood from patients with gastric cancer. Jpn J Clin Oncol 30:499-503.

Misawa K, Kumagai T, Shimizu T, Furihata K, Ota H, Akamatsu T, and Katsuyama T (1998). A new histological procedure for re-evaluation of the serological test for Helicobacter pylori. Eur J Clin Microbiol Infect Dis 17:14-19.

Nakamura N, Ota H, Katsuyama T, Akamatsu T, Ishihara K, Kurihara M, and Hotta K (1998). Histochemical reactivity of normal, metaplastic, and neoplastic tissues to $\alpha$-linked $\mathrm{N}$-acetylglucosamine residue-specific monoclonal antibody HIK1083. J Histochem Cytochem 46:793-801.

Nakayama J (2002). $\alpha 4-\mathrm{N}$-acetylglucosaminyltransferase. In: Taniguchi N, Honke K, and Fukuda M, editors. Handbook of glycosyltransferases and related genes. Tokyo: SpringerVerlag, 151-157.

Nakayama J, Yeh J-C, Misra AK, Ito S, Katsuyama T, and Fukuda M (1999). Expression cloning of a human $\alpha 1$, 4-N-acetylglucosaminyltransferase that forms GlcNAc $\alpha 1 \rightarrow 4 \mathrm{Gal} \beta \rightarrow \mathrm{R}$, a glycan specifically expressed in the gastric gland mucous cell-type mucin. Proc Natl Acad Sci USA 96:8991-8996.

Nicolson GL (1988). Cancer metastasis: Tumor cell and host organ properties important in metastasis to specific secondary sites. Biochim Biophys Acta 948:175-224.

Nishida S, Kitamura K, Ichikawa D, Koike H, Tani N, and Yamagishi H (2000). Molecular detection of disseminated cancer cells in the peripheral blood of patients with gastric cancer. Anticancer Res 20:2155-2159.

Patino JF (1994). The current management of gastric cancer. Adv Surg 27:1-19.

Pectasides D, Mylonakis A, Kostopoulou M, Papadopoulou $M$, Triantafillis $D$, Varthalitis $\mathrm{J}$, Dimitriades $M$, and Athanassiou A (1997). CEA, CA 19-9, and CA-50 in monitoring gastric carcinoma. Am J Clin Oncol 20:348-353.

Piva MG, Navaglia F, Basso D, Fogar P, Roveroni G, Gallo N, Zambon CF, Pedrazzoli S, and Plebani M (2000). CEA mRNA identification in peripheral blood is feasible for colorectal, but not for gastric or pancreatic cancer staging. Oncology 59: 323-328.

Seto Y, Shimoyama S, Kitayama J, Mafune K, Kaminishi M, Aikou T, Arai K, Ohta K, Nashimoto A, Honda I, Yamagishi H, and Yamamura Y (2001). Lymph node metastasis and preoperative diagnosis of depth of invasion in early gastric cancer. Gastric Cancer 4:34-38.

Shimizu F, Nakayama J, Sugiyama A, Kawasaki S, and Katsuyama T (2000). Gastric gland mucous cells circulate in peripheral blood after endoscopic biopsy of the gastric mucosa. Am J Gastroenterol 95:3017-3018.

Straub B, Muller M, Krause H, Schrader M, Goessl C, Heicappell R, and Miller K (2001). Detection of prostatespecific antigen RNA before and after radical retropubic prostatectomy and transurethral resection of the prostate 
using "Light-Cycler"-based quantitative real-time polymerase chain reaction. Urology 58:815-820.

Sun J, Misumi J, Shimaoka A, Aoki K, and Esaki F (2001). Stomach cancer-related mortality. Eur J Cancer Prev 10:6166.

Victorzon M, Nordling S, Nilsson O, Roberts PJ, and Haglund C (1996). Sialyl Tn antigen is an independent predictor of outcome in patients with gastric cancer. Int J Cancer 65:295300.

Wanebo HJ, Kennedy BJ, Chmiel J, Steele G Jr, Winchester D, and Osteen R (1993). Cancer of the stomach. A patient care study by the American College of Surgeons. Ann Surg 218:583-592.
Yeh KH, Chen YC, Yeh SH, Chen CP, Lin JT, and Cheng AL (1998). Detection of circulating cancer cells by nested reverse transcription-polymerase chain reaction of cytokeratin-19 (K19): Possible clinical significance in advanced gastric cancer. Anticancer Res 18:1283-1286.

Zhang MX, Nakayama J, Hidaka E, Kubota S, Yan J, Ota H, and Fukuda M (2001). Immunohistochemical demonstration of $\alpha 1,4-\mathrm{N}$-acetylglucosaminyltransferase that forms GlcNAc $\alpha 1,4 \mathrm{Gal} \beta$ residues in human gastrointestinal mucosa. J Histochem Cytochem 49:587-596. 